\title{
Recent research on vaccines and prevention of Typhoid fever
}

Myron M. Levine

\begin{abstract}
Abstrak
Penyebaran galur S. typhi multi resisten pada tahun 1990-an menjadikan perhatian tertuju pada pemakaian vaksin tifoid untuk mengatasi demam tifoid. Populasi yang menjadi sasaran penggunaan vaksin tifoid tersebut termasuk anak-anak di negara-negara sedang berkembang, wisatawan, dan para ahli mikrobiologi klinik. Selama tahun 1980-an terdapat dua vaksin tifoid baru termasuk S. typhi Ty2 la sebagai vaksin oral dan vaksin Vi polisakarida kapsul yang dimurnikan. Pada percobaan lapangan, kedua vaksin tersebut memberikan proteksi sedang, selama 3-7 tahun. Sementara kedua vaksin ini dapat menggantikan vaksin lama yaitu vaksin parenteral yang terdiri dari sel kuman mati pada para turis, vaksin-vaksin tersebut tidak dapat dipergunakan untuk mengatasi tifoid endemis di negaranegara berkembang. Pejabat kesehatan di negara berkembang menyatakan bahwa tidak cukup dana untuk melakukan vaksinasi Ty2la dan Vi pada anak-anak sekolah, yaitu usia di saat mana vaksin ini diketahui efektif. Mereka lebih tertarik pada vaksin yang dapat diberikan kepada bayi-bayi berumur 0-12 bulan melalui program imunisasi. Vaksin Ty2la dan Vi tidak imunogenik pada bayi, untuk hal ini sedang dicari vaksin yang lebih imunogenik. Konjugat Vi, di mana Vi diikat dengan protein karier seperti toksoid tetanus, memberikan titer antibodi Vi yang tinggi secara bermakna dan merangsang immunologic memory. Selain itu, tiga galur S. typhi hasil rekayasa genetik CVD 908-htrA, Ty800 dan $x 4073$ cukup menjanjikan sebagai vaksin oral dosis tunggal, diharapkan vaksin-vaksin ini lebih imunogenik pada bayi. Apabila vaksin-vaksin ini memberikan proteksi jangka panjang sampai usia sekolah, maka mungkin dapat dipergunakan pada program kesehatan masyarakat untuk mengatasi tifoid di daerah endemis.
\end{abstract}

\begin{abstract}
The spread of multi-resistant strains of S. typhi in the 1990s has invigorated interest in typhoid vaccines as tools to assist in the control of typhoid fever. Target populations for typhoid vaccines for typhoid vaccines include children in developing countries, travelers and clinical microbiologists. During the 1980s, two new typhoid vaccines were licensed in many countries, including Salmonella typhi Ty2 I a as a live oral vaccine and purified Vi capsular polysaccharide as a parenteral vaccine. In controlled field trials, these vaccines conferred a moderate level of protection for 3-7 years. Whereas the well-tolerated Ty21a and Vi vaccines replaced the old reactogenic killed whole-cell parenteral vaccines in travelers, they were not readily adopted by developing countries for control of endemic typhoid. Health authorities in developing countries contend that they lack the resources to administer Ty2 Ia and Vi to school children, the age group in which these vaccines are known to be protective. Rather, they express interest in typhoid vaccines that could be administered to infants 0-12 months of age through the Expanded Program on Immunization. Since neither Vi nor Ty2la is satisfactorily immunogenic in infants, more immunogenic vaccines are being sought. One highly promising approach consist of Vi conjugates in which Vi, after being covalently bound to a carrier protein such as tetanus toxoid, elicits significantly higher titers of Vi antibody and stimulates immunologic memory. In another approach, three new genetically-engineered strains of S. typhi, CVD 908-htrA, Ty800 and $x$ 4073, offer promise as single-dose live oral vaccines. It is anticipated that these new vaccines will be markedly more immunogenic in infants. If they confer long-term protection enduring through school age, they may serve as public health tools to control typhoid in endemic areas.
\end{abstract}
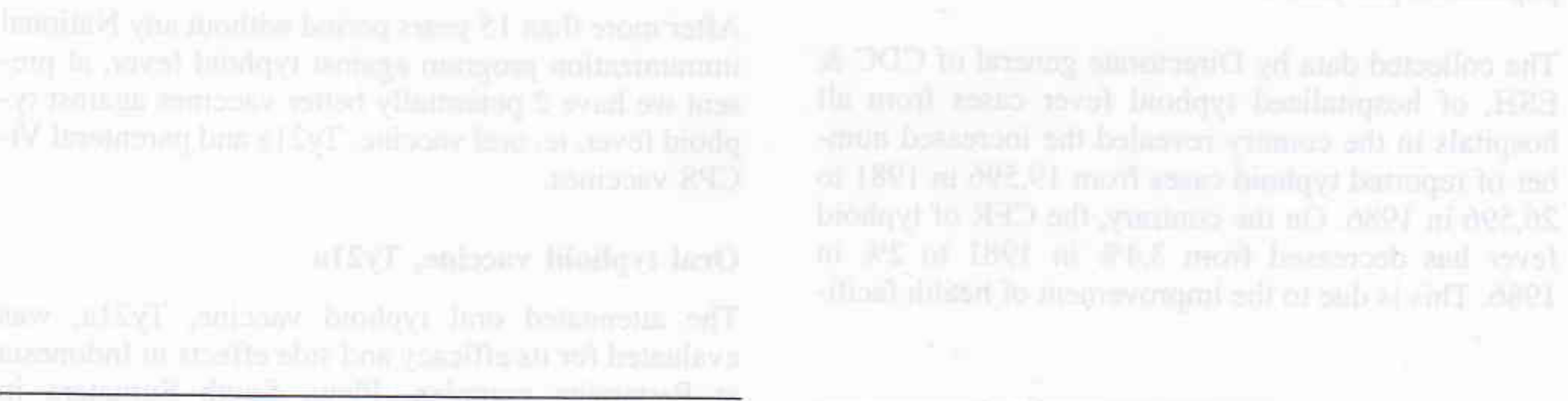

Center for Vaccine Development,

University of Maryland, Baltimore, Maryland, USA 